\title{
International business development and the internet, post-hype
}

\author{
Petersen, Bent; Welch, Lawrence S.
}

Document Version

Final published version

Publication date:

2002

License

CC BY-NC-ND

Citation for published version (APA):

Petersen, B., \& Welch, L. S. (2002). International business development and the internet, post-hype.

Link to publication in CBS Research Portal

\section{General rights}

Copyright and moral rights for the publications made accessible in the public portal are retained by the authors and/or other copyright owners and it is a condition of accessing publications that users recognise and abide by the legal requirements associated with these rights.

\section{Take down policy}

If you believe that this document breaches copyright please contact us (research.lib@cbs.dk) providing details, and we will remove access to the work immediately and investigate your claim. 
WP-8, 2002

\section{INTERNATIONAL BUSINESS DEVELOPMENT} AND THE INTERNET, POST-HYPE

Bent Petersen

Lawrence S. Welch 


\title{
INTERNATIONAL BUSINESS DEVELOPMENT AND THE INTERNET, POST-HYPE
}

\author{
Bent Petersen \\ Associate Professor of International Business \\ Department of International Economics and Management \\ Copenhagen Business School, Denmark. \\ Howitzvej $60,2^{\text {nd }}$ floor \\ DK-2000 Frederiksberg C \\ Tel: (+45) 38152510 \\ Fax: (45) 38152500 \\ e-mail: bp.int@cbs.dk \\ Lawrence S. Welch \\ Professor of International Marketing \\ Mt Eliza Business School, Melbourne, Australia.
}

\begin{abstract}
In this paper we examine a range of effects of the Internet on international business development following the collapse of speculation and hype surrounding the 'Internet bubble' in the recent past. Internet effects are considered by focusing on different dimensions of firms' internationalisation: specifically, internationalisation capacity, as represented by strategy, structure, technology, human resources and financial resources; and internationalisation patterns. While the Internet may have been over-hyped during the recent 'bubble' stage, there is little doubt that it has affected many aspects of companies' international operations - accelerating some stages of development, although it would appear that firms are still learning how to productively incorporate the power of the Internet across the full range of their international operations in different markets, and develop a better fit with traditional forms of operation.
\end{abstract}




\section{Introduction}

At the beginning of the new millennium developments in the use and spread of different applications of the Internet in international business were seen by many as heralding a new era of business in which distance barriers would be removed ( Economist 1995, Mol/Koppius 1999). Even the term 'international' was seen as taking on a new meaning in a 'borderless market space'. Clearly, reality has not matched the hype, and with the crash of many Internet/e-commerce related businesses it is an appropriate point to reassess where the Internet 'revolution' has taken international business so far and the implications for future development.

There is no doubt that the Internet - constituting an easy-to-access, worldwide network has already had a significant effect on the conduct of international business and that this impact, despite the recent downturn in Internet-related businesses, is likely to continue, changing many aspects of international business in the future, although not necessarily in ways, and at the speed, that might have been expected looking ahead from the middle of the boom. Even in the boom, it was becoming clear that international expansion through the Internet posed many problems that did not have simple 'virtual solutions': for example, distributor relations could be seriously impaired by moves to bypass distributors in favour of direct dealing via the Internet; and Internet-based international retailers were already facing difficulties in expanding operations without establishing an old-style presence in foreign markets (Petersen et al, 2002).

In this article we overview major effects of the Internet on firms' internationalisation not only those effects that are generally recognised, but also unresolved key issues. Taken together, the unresolved issues identified make up a research agenda for the study of 
international business development in the digital age of the 21 st century. The electronic linking together of individuals, institutions, and companies in a worldwide web has created an unprecedented public data base that heralds the ultimate realisation of the information society. In this perspective, the worldwide spread of Internet use is much more than an incremental advance of information and communication technology (hereafter I\&CT). Hence, when reviewing the effect of the Internet on international business development we seek to separate, on the one hand, the pervasive effects of the advances within I\&CT in general, including digitisation, and, on the other hand, the specific effects of the Internet, including e-commerce. Furthermore, we focus on the external communication attributes of the Internet - the globally ubiquitous point-andclick interfaces based on open standards - rather than on the internal (intra-firm) communication network properties.

Our overview includes a range of impacts of the Internet on the way in which international business is evolving. We focus on firms' internationalisation, with reference to aspects such as patterns of internationalisation, mode effects, distributor relations and the role of language. We consider the effect of the Internet on the digitisation of products, and thereby the way in which companies may be able to develop international operations, and the importance of intellectual property right regimes for patterns of international expansion. In addition, we examine a number of management issues associated with increasing use of the Internet, including the management of people in a multinational context. Figure 1 presents a framework which we have employed in considering the various impacts of the Internet - adapted from Welch and Luostarinen (1988).

\section{---- Figure 1 about here ---}

The figure presents two sides of a firm's internationalisation: its internationalisation pattern and its internationalisation capacity. A firm's internationalisation pattern refers to the different dimensions of the activities performed outside the home country - the What? How? Where? and When? questions. The internationalisation capacity of a firm refers to a company's prerequisites for involving itself successfully in (further) 
international activities and the motivation of the company's decision makers to operate internationally. At a basic level a firm's internationalisation capacity is shown as being composed of its resource base (technological, human, and financial) that is a requisite for successful completion of international business ventures. In addition, the internationalisation strategy and organisational structure and processes of the firm are considered to be part of a firm's internationalisation capacity. Our overview of I\&CT and Internet effects begins with an examination of their impact on firms' internationalisation capacity.

\section{Impact of the Internet on Firms' Internationalisation Capacity}

\section{Technology / Production Economies}

On the demand side, it is apparent that I\&CT advances have provided a strong impetus for firms to become involved in international business operations - along with the fact that the Internet has greatly enhanced firms' ability to spot international business opportunities. On the supply side, internationalisation implications of I\&CT advances are less unidirectional. As far as technology and production economies are concerned the impact of I\&CT advances on internationalisation differs significantly between producers of 'traditional' physical goods and producers of digital information goods. Digital information goods (henceforward referred to as "e-products") typically are characterised by high fixed costs and negligible marginal costs, so that after having incurred up-front investment costs, the producer has a strong incentive to offer the e-product to as many customers as possible. Thus, the cost structure of e-products encourages the producer to achieve global scale economies. Moreover, e-products often are subject to "network externalities", by which the utility that the individual customer derives from the eproduct increases roughly in line with the square of the number of other users (Shapiro/Varian 1999, see also article by Mahnke/Venzin in this special issue). Together, scale economies and network externalities provide a strong incentive for e-product providers to expand beyond the home market. 
In contrast, it could be argued that I\&CT advances in general have diminished the motivation for producers of physical/non-digitised goods to expand internationally. Because of information technology development, many producers have digitised their manufacturing processes in order to enhance precision and save manual work. As an important side-effect, the digitisation of production processes has also reduced the costs of switching from one line of manufacturing to another, thereby enabling more flexible production with a lower minimum efficient scale of operations (Westbrook/Williamson 1993, Halliburton/Jones 1994). Furthermore, I\&CT investment costs, relative to output, have gone down dramatically over the past two decades (Economist 2000). Both of these I\&CT effects have pulled in the direction of making small-scale production more economical. All else being equal, better economic conditions for small-scale production reduce firms' incentive to involve themselves in international business operations because the probability has increased that demand in the home market will exceed the minimum efficient scale of local production. Also, with more flexible production the risk of excess production capacity diminishes. Excess production capacity is considered to be an important motive for export involvement (Albaum et al. 2001). Hence, I\&CT advances in terms of digitisation would appear to have reduced the pressure on producers of physical goods to go international due to production economies.

To sum up: via its influence on production economies, digitisation of production processes tends to decrease some firms' motivation to internationalise, whereas the digitisation of products is likely to increase firms' inclination to go international. However, the distinction between providers of physical goods and e-products is blurred. Today, few firms are purely physical good providers inasmuch as auxiliary services are attached to most goods, and in recent times many of these services have to a large extent been digitised (e.g. after-sales services offered through the producer's website). As this digitisation of services proceeds, firms' incentive to internationalise should grow correspondingly.

If we look at how the Internet affects the interplay between firms' production economies and internationalisation economies of scope, rather than of scale, the Internet has 
enhanced the possibilities of finding potential foreign partners in possession of complementary assets with which a firm may share production facilities and technology. One may suspect the realisation of scope economies via the Internet to be more important to small and medium-sized firms than to large, multinational firms. The proliferation of portals on the Internet provides evidence about firms' sharing of (scarce) resources enabling the incumbent portal firms to serve the needs of the individual customer in a more comprehensive way than individual entities can do single-handedly.

Apparently, digitisation of goods and services together with the improved inter-firm communication opportunities offered by the Internet have changed production economies in ways that give firms a strong impetus to internationalise. However, the increased incentive to internationalise is common to all firms in an industry across countries (although in some industries country-specific differences in level of IT infrastructure sophistication may be substantial). With more firms catering to customers outside their home market international competition inevitably becomes stronger. The crucial question for a firm's management, therefore, is to what extent improved production economies via internationalisation are matched by international competitors pursuing similar scale and scope economies? The Internet appears to be an excellent instrument for gauging a firm's competitive advantage in an international setting. With its outstanding search capabilities, the Internet may assist the individual firm in benchmarking itself against its international competitors. On the other hand, strategic information about technology, or other sources of competitive advantage, is not readily available on the Internet. Hence, whereas the Internet undoubtedly is an excellent mediator of information about demand side conditions in international markets, it is an unresolved issue as to what extent the Internet is of use when it comes to supply side information.

\section{Human Resources - Managing People}

The Internet has had important effects on the way in which people are managed within international companies. How the process is handled may well have profound implications for the capacity of companies to internationalise and handle its outcomes. The ability of companies to develop global operations increasingly via the Internet 
depends on staff being able to initiate and carry through a range of new activities and deal with a variety of new technologies. This will place major demands on the human resources function to find the appropriate staff, either inside or outside the organisation. A range of new skills has to be developed, not the least being, for some, to operate in a cross cultural environment without the normal person-to-person exchanges (Petersen et al., 2002). This is probably the most demanding aspect of global e-commerce, although the emergence of international call centres has demonstrated that staff can be trained to undertake a range of functions, and communicate with customers in a variety of languages, and even dialects, in a relatively impersonal international environment. The rapid growth of call centres and document processing facilities in India has demonstrated something of the possibilities in this area (Economist 2001). Moves in this direction, however, make it somewhat more difficult for management to decide when it may be necessary to move between e-servicing and more traditional forms of customer servicing. In establishing centralised e-response systems, companies can create barriers to the holistic, seamless servicing of customers (Widdows/Widdows 1999). Particularly in cross-cultural situations, companies will often have to develop person-to-person encounters with foreign customers at an early stage in the process of foreign market entry. The link between e-servicing and more personalised approaches to foreign customers, therefore, may depend on some individuals who can move easily between these different forms of customer servicing. Again, the demand on higher levels of training and skills may be considerable, as well as greater flexibility on the part of staff. It would seem that companies using the Internet in the international arena are only just coming to terms with the demands and possibilities of the new Internet-driven environment for staffing and training issues.

While the Internet itself is likely to alleviate some of these demands, such as via elearning, it cannot be viewed as a 'cure-all' in international operations. Recent research in Denmark (see article by Welch, Worm and Fenwick in this issue) illustrates this in respect to the growth of so-called virtual assignments (i.e. managing a foreign staff activity via the Internet rather than in-person). Their use has been supplemented by a rise in short term assignments. Ultimately, there would appear to be some scope for a 
reduction in the need for staff movement internationally. I\&CT advances have already improved conditions for expatriation and short term assignments by making it much easier for the expatriate and his/her family to keep in contact with their networks back home. With the Internet, however, conditions for virtual assignments have improved significantly as well. The interest in virtual teams and virtual assignments reflects an effort on the part of many companies to derive benefits from Internet technology in the way they organise and manage staff activities within their international operations (Kayworth/Leidner 2000). Foreign assignments, no matter how short they are, represent a costly side of international firms' operations, and therefore a continuing incentive for the search for alternatives (Dowling et al, 1999).

\section{Financial Resources}

I\&CT advances in general have been important drivers of the convergence of costs of capital of firms during the last decade (Oxelheim 1997, see the article by Globerman in this issue). As a result of this process of transition from independent national financial markets to a more integrated, globalised market international firms have, all else being equal, lost competitive advantage vis-à-vis domestic firms operating in what previously may have been high-cost capital markets. Since the availability of cheap and abundant (venture) capital in global markets currently appears to be declining, firms' incentive to internationalise should diminish accordingly. However, through the creation of more transparency across markets, I\&CT advances, and the Internet in particular, may reduce the disadvantage of foreignness in terms of being unknown to local investors.

Assuming that the Internet has the effect of increasing the pace of internationalisation for example, opening up a wider range of foreign markets that can be served - the ability to finance expansion may become a critical issue, particularly for new Internet-related ventures in the post "Internet bubble" world. A study of a small number of internationalising, Internet-based Norwegian firms indicated that while it was relatively easy to obtain finance (via investors) to support international expansion in the Internetpositive environment of the late-1990s, this has become much tougher today, leading to cutbacks in international commitments (Borsheim/Solberg 2002). The Internet should 
facilitate greater transparency about financing options on an international basis, thereby adding to pressure for lowering the cost of capital across countries. This could be an important consideration for Internet-related new ventures given the variability of markets for new venture finance.

\section{International Strategy / Organisational Structure and Processes}

Whereas I\&CT advances have supported firms' strategies of multinationality and transnationality (Bartlett/Ghoshal 2000, Cohendet et al. 1999), the advent of the Internet seems to have placed pressure on international companies for increased global integration and coordination (Roche 2000). The expectation at the height of the Internet boom was that international companies would experience a stronger need for global standardisation as a result of increased transparency across national markets . This, in turn, would force international firms toward stronger central coordination and control mechanisms, involving closer integration of their dispersed activities. As an example of Internetinduced transparency, pricing policies in different national markets would need to be brought more closely into line (Roche 2000). Inevitably, such a change would force a whole range of adjustments throughout the international company in areas such as purchasing, supply chain management, and marketing programmes. As a reflection of this move towards centralisation, some international companies introduced websites for the corporation as a whole, and for international operating companies in non-English speaking countries, such as Denmark, the website would normally be in English. The centralisation bias of the Internet has been reinforced by the perceived strategic importance of online sales by international companies so that the direction and control of developments have been driven by headquarters - it has been seen as being too important to leave to the various subsidiaries. This has been applied in particular to testing in the marketplace of online sales of existing as well as new products (Confederation of Danish Industries, forthcoming). It is somewhat ironic that in the digital age there seems to be something of a return of the product life cycle pattern stressed in earlier development of international business patterns (Burenstam-Linder 1961, Vernon 1966). 
However, the extent to which the Internet has changed markets in the direction of becoming more transparent and price competitive is open to question (see the article by Chakrabati/Scholnick in this issue). There are undoubtedly areas where this has occurred (Yip 2000), and the processes are continuing, but in reality companies have been able to maintain strategies of differentiation in many areas of business across global markets. In part they have been able to do this because of increasing skills in utilising the Internet to strengthen supplier and customer relations in a way that adds value to the product offer. The increasing use by companies of the Internet as a platform for extranets that more effectively link companies to suppliers and customers has been an important element of this evolving process. Furthermore, the website has become another element of this process, allowing companies to separate and inform suppliers and customers as part of building longer term relations. In an Australian study of the use of e-commerce by SMEs, a number of companies were found to have reached the stage of integration with their trading partners via the web site, linking internal business systems and processes (Marshall/McKay 2002). This becomes even more important in various foreign markets because of language and cultural differences. Finally, the marketplace of tomorrow may very well witness pressure for increased local responsiveness enabled by I\&CT, an element of the move to "mass customisation" heralded by some marketers (Halliburton/Jones 1994, Kotha 1995, Westbrook/Williamson 1993), and fuelled by antiglobalisation sentiments among consumers. Local responsiveness will not necessarily comply with national borders, but may appear as a super-segmentation phenomenon where the individual customer requires special treatment.

Despite the many claims of the changed world in the digital age, it would appear that many of the 'old' management issues remain: companies still have to balance the conflicting pressures of local responsiveness while maintaining managerial oversight, control and coordination from headquarters. 
So far, we have discussed a range of impacts of the Internet and e-commerce developments on the internationalisation of companies - as reflected in their internationalisation capacity (see lower part of Figure 1). Some of the main effects are summarised in Table 1. As well, though, there are important effects of the Internet on the way firms carry out international business operations (reflected in their internationalisation patterns - see Figure 1, upper part), and it is to these impacts we shall now turn.

\section{The Impact of the Internet on Firms' Internationalisation Patterns}

Pace

As yet, there has been limited research on the impact of the Internet on the internationalisation of firms, particularly of a longitudinal nature. Nevertheless, it seems evident that the Internet has enabled much faster internationalisation to occur for some firms, and the speeding up of processes at certain stages for other companies (Lituchy/Rail 2000, Vahlne/Johanson 2002). The accelerated internationalisation induced by the Internet is mainly due to demand side effects: companies are pulled into foreign markets via their greater visibility to customers using the Internet to search for products and services. Thereby, the Internet effect on the pace of firms' internationalisation differs from the general effect of I\&CT advances that have been more supply side oriented. For example, as a result of I\&CT advances, the lead time of technology development has shortened, which in turn has tended to result in international companies accelerating their penetration of foreign markets.

Depending on the type of product or service, some companies have been able to achieve global spread in a relatively short space of time by operating solely via the Internet, e.g. dot.com. companies and Internet consulting companies (Economist 1995, Vahlne/Johanson 2002). As well, the Internet has facilitated processes such as international information searches, exchange of information, and through the web site the potential means of relatively instantaneous contact with the rest of the world. It can be 
argued that the Internet has 'reversed' the constraint posed by lack of information/knowledge about foreign markets shown in widespread research on exporting firms to being one of pulling firms into international markets (Leonidou/Katsikeas 1997, McAuley 1993, Seringhaus 1986). In a review of the research on export barriers, Leonidou (1995, p. 40) concluded that "limited information to locate/analyze foreign markets had the greatest inhibiting impact on the firm's ability to initiate or develop exports".

The Internet probably has ensured that the "born global" (or international new venture) phenomenon (Knight/Cavusgil 1996, Madsen/Servais 1997) is a more commonplace reality in the process of firms' internationalisation - increasing the likelihood of fortuitous international Internet contact and unsolicited contact via a company's web site whether international sales were an objective or not (Quelch/Klein 1996, Yip 2000). This process has undoubtedly been reinforced by the actions of different countries' trade promotion bodies which have become active in using the Internet in various ways to enhance the potential of local companies to connect with potential foreign customers. An example is a recent initiative by the Japan External Trade Organization (JETRO) in which Japanese IT companies interested in doing business with Australian IT firms were introduced to potential Australian clients via the Internet (JETRO 2002).

While the Internet is likely to positively affect the rate of firms' internationalisation, the effect is by no means certain: much depends on the interplay between culture and the greater rate at which people are contacting each other via the Internet. It is conceivable that greater contact could be a cross-cultural negative, i.e. the Internet may well connect people prematurely, without the preceding development of cross-cultural familiarisation. Leamer/Storper (2001) argue from the perspective of economic geography that increasing economic development has placed even greater stress on the transmission of complex messages and data through face-to-face contacts that the Internet can never replace.

\section{Product / Value Chain Activity}


The potential of the Internet for trading purely e-products has spawned a new array of digitised products.

---Insert Figure 2 about here ---

As shown in Figure 2, many of these products are aimed at servicing the use of the Internet and facilitating e-commerce activity - especially different types of software connected with payments, security systems, customer profiling, etc. The Internet has also stimulated new developments in the field of machine translation as different languages are used on web sites and through the Internet (Economist 2002). As well, many "old products" are becoming digitised, thereby allowing them to be sold and transferred through the Internet; for example, the emergence of so-called e-books. Such books are being sold by publishers alongside Internet sales of physical books (e.g. by Amazon) and the continuing use of retailers selling directly to the public. There has been, similarly, an expanded range of 'entertainment' products that have been digitised and offered via the Internet, such as films and music, that co-exist with traditional forms of delivery. Of course, companies will often be selling a mix or combination of purely e-products and those of a traditional, physical kind. The digitisation of products in combination with the Internet as an inter-firm collaboration facilitator (e.g. as manifested by the appearance of Internet portals) has also been seen as an opportunity for firms to provide more comprehensive product solutions to their customers (Gupta 2002).

In addition to a possible digitisation/Internet-induced shift from discrete products to comprehensive customer solutions, digitisation holds the potential for changing the focus of firms' overseas value added activities. The digitisation of products first of all has implications for the market-seeking value chain activities that firms undertake abroad: other things being equal, digitisation should mean less need for localisation of marketing and sales activities abroad (later, we will discuss the validity of this argument). Other value chain activities, such as research and development, are less amenable to digitisation because personal networks and tacit knowledge are important components, and resource 
seeking activities (raw material extraction, exploitation of cheap labour, etc.) are even less affected by digitisation.

Some services (e.g. car repairs) are bound to remain physically oriented, but others may be shifted to delivery over the Internet. To the extent that after-sales service can be handled via the Internet, companies will feel less pressure to set up on the ground servicing arrangements in foreign markets, and may be able to avoid foreign direct investment in some cases. Yip (2000, p.12) maintains that "many companies now handle much of their global after-sales service through their websites. Cisco, for example, provides $80 \%$ of its service over the web". In much the same way as systems sales typically involve a combination of goods, services and know-how, increasingly complex combinations of e- and non e-products and services can be expected to develop. Expanded e-product and service offerings and their utilisation are bound to increase in the near future as mobile telephones increasingly come into play as an alternative, even preferred, means to receive Internet-based products and services.

Clearly, much of the digitisation of products and services is driven by a range of influences, not only those tied to Internet use, as shown in Figure 2. However, the Internet is an important driver in this process. Likewise, the possibility of translating such product development into an expansion of options for global e-commerce expansion is an important factor. Developments noted above can be seen as facilitating other aspects of companies' internationalisation: e.g., the pace of internationalisation, the spread of markets served and the ability to avoid a shift to more traditional forms of foreign operations. At the same time though, intellectual property rights (IPR) regimes and associated legal problems have tended to act as a constraining influence on the facilitating benefits of digitisation, affecting product development in two important ways: (1) constraining the development and international marketing of e-products which are difficult to protect; (2) biasing the development process towards products which will enhance security on the Internet and IPR protection. We will return to these IPR aspects when discussing firms' selection of foreign markets. 
While early internationalisation processes may be facilitated by the Internet, sporadic evidence indicates that even purely Internet-based firms find it difficult to operate internationally without establishing local, physical facilities, e.g. representative offices, at some stage, thereby slowing internationalisation at a later stage. The Danish dot.com company, Speednames (a wholly-owned subsidiary of Ascio Technologies Inc.), provides an example of how difficult it may be - even for companies selling purely digitised products - to reach customers outside the home market. Since its inception in 1999, Speednames has offered worldwide sales of Internet domain names as a digital domain name registrar. Speednames operates as an intermediary between the local domain name authority, called Registry, and individuals or business organisations that want a domain name. Global identity is of strategic importance to the company: it has deliberately disguised its national (Danish) identity. The website (www.speednames.com) gives information in nine different languages. As part of its international marketing, Speednames appears on all important Internet search engines in order to be visible to customers looking for domain name providers. Despite all of these online marketing efforts, a customer survey (Summer 2001) showed that more than $50 \%$ of Speednames' customers were domiciled in Denmark. The bigger markets of the USA $(6 \%$ of Speednames' customers), Sweden (6\%), the UK (5\%), Germany (3\%) and the Netherlands (3\%) contributed relatively few customers. Speednames' low penetration of the international market points to the importance of conventional - and very localised communication channels (word-of-mouth, exposure in Danish business magazines, etc.) rather than online promotion. Recognising the limits of online promotion as a stand-alone marketing tool, by Spring 2002 the management of Speednames had considered using new, supplementary operation modes - such as franchising and sales agencies - in its more important foreign markets (personal communication with Product Manager, Christine Agger-Nielsen and Managing Director, J. Helbrandt).

The case of Speednames is in line with the findings of a recent study of Internet users in twenty countries (Lynch/Beck 2001). The study indicated that being online was not enough to produce global operations. Customers still looked for localisation (context/culture) in their online experience. Similarly, in a study of a small number of 
Norwegian born global, Internet-based firms, it was found that even when direct exporting via the Internet was used, it was quickly followed by other forms of operation in the foreign market (Borsheim/Solberg 2002).

For those firms producing physical products for export, the perceived need to localise will sometimes come quite early as a result of the complexities of physical distribution, e.g. for foreign wine companies in coping with diverse State laws regarding the sale of alcohol in the US. In whatever form foreign operations occur after Internet driven sales have taken place, firms will have to confront a range of new demands and commitments that will inevitably slow down the rate of internationalisation. It is unclear how much of the learning and network development that occurs through Internet-based internationalisation can be adapted to non-Internet-based operations. The new operations are likely to require a range of new learning tasks, including the role of the Internet in combination with more traditional operation forms (Petersen et al 2002).

\section{Foreign Operation Mode Effects}

Having recognised the need for a local, physical presence in the foreign market, companies have to decide whether such operations should be internalised or not (Buckley/Casson 1976). The general view is that I\&CT advances favour externalisation because the possibilities for enforcing contracts entered into with local operators are enhanced (Blaine/Bowen 2000). The opportunities for the contract partner to shirk would be mitigated by online monitoring, access to data bases, integration of accounting systems and the like, of the contractual partners (Marshall/McKay 2002). As an example, some franchisors have been able to achieve very close monitoring of their franchisees' operations including sales data, ordering systems, customer behaviour (data mining), etc. through the use of on-line linkages and software. In addition, I\&CT advances have reduced not only the costs of enforcing market contracts (market transaction costs), but also the costs of coordinating the activities of the multinational company. With a simultaneous reduction of transaction and coordination costs, the net effect of I\&CT advances in terms of foreign operation modes is difficult to predict. In a similar vein to Internet effects, at the outset the Internet was predicted to accentuate the externalisation 
effect of I\&CT advances because companies, through the Internet, would experience better opportunities for detecting suitable contractual partners, such as franchisees, in foreign markets. As a result, the Internet could be expected to provide a fillip to franchising's development internationally. Franchising companies in many cases are seeking to build a global concept for which the Internet is well-suited (Yip 2000). The Internet is suited also to publicising and promoting opportunities to potential franchisees and in generating approaches from them. The Internet should also allow the franchisor to be more responsive to franchisees and their customers - adding value to the customer offer in a way that could dramatically change the balance between franchisor and franchisee, especially when this is put alongside the enhanced monitoring capabilities via I\&CT advances, including the Internet. As a result, franchisors may look for increased returns from franchisees.

However, the pressure for global coordination mentioned earlier may force international companies into internalisation simply because a very high control of the international affiliate network is required. Hence, it is difficult to establish whether or not I\&CT advances and the Internet promote contractual modes rather than internalisation. Furthermore, empirical evidence of a trend towards more use of contractual forms in international operations is problematic inasmuch as there may be substantial time lags in relation to change of existing organisational forms, and because an externalisation effect may 'drown' in countervailing effects, such as information overload and an increasing importance of tacit knowledge as a competitive advantage factor (Daft/Lengel 1986, Blaine/Bowen 2000, Leamer et al. 2001).

Whereas it is difficult to predict I\&CT/Internet effects in terms of externalisation/internalisation it is less disputable that the Internet - in combination with digitisation - will result in expanded exporting activity. If the technology allows companies to operate on a purely electronic basis, or nearly so, then we can describe the 'cross-border' activity in cyberspace as a type of exporting - Internet exporting. Where physical goods are involved, the Internet should allow companies to operate as exporters without the same pressure to move to other forms of operation such as foreign 
subsidiaries. As noted above, the reality has proven somewhat different, i.e. there is still pressure to set up local, physical facilities - examples of local, non-physical presence of an entrant dot-com firm are a local domain site or a specialised foreign language website focused on the local market, but under a country-of-origin domain (Kotha et al. forthcoming). While the Internet can do some things well - e.g. initial contact, etc. there is still the need to relate to customers in a more direct way in their own environment. Internet exporting exposes a company to competitive approaches via the same medium. An issue, then, is how to lock in foreign customers. How best to do this is still an open question for companies.

As to the Internet potential for bypassing middlemen that has been predicted (see e.g. Wunderman 1998), thereby diminishing the role of agents/distributors, this does not appear to have eventuated, certainly not at the rate which has been predicted (Coltman et al. 2001, Sarkar et al. 1998). There are numerous, often high-profile, examples of companies becoming involved in damaging conflict with their distributors/retailers in the process of attempting to develop direct online sales, e.g. Compaq in Australia, Lego in the U.K, and Levi Strauss in the US. A study of 50 manufacturers found that the biggest issue facing them in selling online was channel conflict - far above any other issue (66 \% mentioned channel conflict) (Allen 2000). One might argue that in an international business context the difficulty of bypassing a local intermediary is even more pronounced due to cultural and communication issues. The focus of the research in this area has tended to be on the potential channel conflict between manufacturer and distributor, with an implicit assumption that the manufacturer has the upper hand with regard to the development of online operations. However, it cannot be excluded that a distributor will have developed sophisticated online outlets and associated distribution infrastructure, to the extent that the distributor has a significant advantage over the foreign firm through a combination of Internet and physical distribution activities. In fact, there is every reason for the distributor to develop in this direction as a way of warding off the inroads of the Internet into their position in the marketplace. It is conceivable that the distributor with this combination will be in a stronger position than previously. 


\section{Geographical Spread}

The Internet can be expected to accelerate the rate at which certain aspects of internationalisation proceed, but also it creates the likelihood that companies will create costumers in a broader array of countries than was experienced in the past at equivalent stages of internationalisation. This is because of the global exposure consequent upon the establishment of a web site. Markets which may never have been considered feasible due to language or other cultural differences could be opened up by the Internet - often fortuitously. At a macro level, of course, the growth of market diversification options is tied to the rate at which Internet use diffuses globally. Thus, countries' technological infrastructure development, including diffusion rate of Internet users, has been found to be a major country entry choice criterion of US Internet firms (Kotha et al. forthcoming). Assuming they respond to the diverse market options presented, companies will be required to deal with a broader range of cultures than hitherto. In seeking to make their international operations profitable, they will face the question of how much market diversification they can actually handle (Ayal/Zif 1979; Piercy 1981).

The extent of spread will be affected by companies' Internet language policy. Small companies may be ill equipped to handle multiple languages via the Internet. For example, in a study of small inns and bed and breakfasts, Lituchy/Rail (2000, p.95) found that "although they are trying to increase the number of guests from other countries [via the Internet], most of the respondents [operators of the inns and bed and breakfasts] had information only in English". Even large multinationals seem to have had difficulties in developing and operating multilingual web sites (Economist 2002). Thus, language would appear to be an obvious constraint on the extent of market spread by internationalising companies through the Internet. This constraint appears to be growing with the increasing use of own language Internet services in individual countries (D. Welch et al 2001).

Although in the initial stages of global expansion of the Internet English was overwhelmingly the language used in Internet communication and dominated websites, there has been a dramatic reduction in its role in recent times (Global Reach, 2002). 
Increasingly, the Internet and websites have become a vehicle for localisation through the use of local languages, although often associated with an English option (D. Welch et al., 2001). This development parallels what has happened in the provision of

media/entertainment services. For example, in the early stages of European growth of the sports channel, Eurosport, it was dominated by use of English language commentary. However, in the longer term it has been localising by providing commentary in the local language where it is being broadcast, facilitated by improvements in the relevant technology.

Market patterns of firms' Internet-based international expansion also are affected by the type of intellectual property rights (IPR) regime in different countries. By their very nature, digital information goods, or e-products, can be readily copied and reproduced (Shapiro/Varian 1999). The problem for those marketing these products and seeking to derive revenue from them is the difficulty of extracting payment from their use. Examples abound of companies being unable to prevent unauthorised use, and even resale of their e-products. Publishers have been struggling to make e-books a viable commercial entity. To the extent that it is difficult to protect intellectual property, this is likely to constrain the preparedness of companies to develop domestic as well as international e-operations. Very much in contrast to the inherent global nature of ecommerce, the legal systems by which intellectual property rights are overwhelmingly defined in a national or regional context.

It would seem that the issue of intellectual property rights has an effect on the internationalisation of companies in a number of ways. Companies may find that IPR regimes in some foreign countries are weaker than at home, and for this reason exclude these countries as hosting sites for production and, in particular, R\&D entities. The risk of damaging use of companies' e-products may even result in attempts to restrict export sales to customers domiciled in countries with weak IPR regimes - i.e. generating what might be called a 'country-of-destination' bias. Technically, the very nature of e-products makes it impossible to prevent a local customer from passing on e-products to these 'banned' locations, with the intention of reproducing the e-products; but legally, 
companies can more readily take action against the local customer engaged in such activity. Many companies have sought to deal with the problem of dissemination risk by widespread patenting, where feasible, of various aspects of operating systems and software in conjunction with the use of the Internet. Perhaps the best known example is that of the computer assembler and retailer Dell which has taken out many patents on its Internet ordering system. As such, this approach has been an important part of clearing the way for the development of its international marketing operations. In this way, IPR regimes can be an important factor in the general pattern of firms' internationalisation. To some extent it can be argued that the increased importance of the legal environment in the digital age has likewise raised its profile within the psychic distance box.

The above discussion of IPR regimes, culture, language, and technology infrastructure demonstrates that the world of global e-commerce is not seamless, and that country differences in various aspects of e-commerce remain important, shaping resulting patterns of global e-commerce.

The main effects of I\&CT advances and the Internet on firms' internationalisation patterns - as outlined in the four previous sections - are summarised in Table 2.

--- Table 2 about here --- 


\section{Firm's Environment}

As indicated in Figure 1, the development of firms' internationalisation capacity and patterns are, of course, influenced by other environmental factors than the Internet and I\&CT advances in general. Important environmental factors include exchange rate fluctuations, trade bloc developments, governmental export promotion programmes, ecommerce tax regulation, and economic growth in general. Some environmental factors are to some extent influenced by Internet development itself; take as an example the impact of e-learning on the educational level of a country's work force.

We will restrict the discussion to one particular environmental factor, namely country-oforigin effects. This factor has direct implications for firms' export opportunities in the digital age, and may, or may not, be redefined by the Internet. Country-of-origin effects are part of this impact of country differences (Tse/Gorn 1993). Consider the difficulties of a Russian firm attempting to develop international operations through the Internet, with particular emphasis on selling e-products directly to consumers in the US market. To begin with, it is likely to face concerns regarding products and services originating in Russia (assuming this is not hidden), as with physical products. In addition, however, there are other factors further complicating these concerns. Take for example payment systems where there has been a reluctance on the part of consumers in many countries to undertake payment by credit cards because of security concerns (Oxley/Yeung 2001). The need to put credit card details into the hands of Russian companies is likely to constrain the preparedness of US consumers to become involved in Internet purchases from such companies - thus reinforcing perceived country-of-origin concerns. The establishment of a US domain website may reduce the concerns of US customers, but not eliminate them.

One solution for the Russian company would be for it to establish a US-based, physical facility in a way which would allow it to utilise a made-in-US label. This could apply to both physical and e-products. In general, there is some evidence that e-commerce and 
related companies are moving quite early to establish offices in countries which they are seeking to penetrate (Borsheim/Solberg 2002, Vahlne/Johanson 2002).

\section{Conclusion and Implications}

From an overview of the way in which the Internet and its many manifestations are affecting companies' continued development of international operations, one might conclude that 'the Internet hype is dead, long live the Internet'. Companies have not stopped looking at ways of more effectively using the Internet in their international activities, although the crash of the "Internet bubble" may have taken off some of the perceived pressure to push ahead rapidly. As a result, companies should be in a better position to weld together what the Internet is capable of delivering with the strength of traditional approaches - perhaps this is the most important change in approach 'posthype'. Porter (2001) stresses the importance of linking traditional forms of doing business with on-line approaches in the development of strategy. He quotes the case of one US distributor which found that the distribution of its printed catalogue resulted in increased on-line sales. This is particularly important in an international context, where cross-cultural exchanges are a constant challenge. An illustration is the continuing difficulty that even large multinationals have in coping with a multiplicity of languages. As yet, technological solutions have provided only a limited answer, and it is evident that, in general, the power of face-to-face relations is difficult to replace, as is the role of distributors in foreign markets.

Already, it has become evident that in analysing the impact of the Internet on internationalisation there needs to be more attention paid to time and process effects. For example, it seems to be broadly accepted that the Internet will play an increasing role in initial contact between companies and their foreign customers, reinforced by various governments' Internet-related trade promotion activities, and generating more so-called 'born global' firms. However, over time it is likely that the Internet will play a more complex role in the process of foreign market servicing - interacting with other approaches such as foreign market visits, foreign intermediaries, external advertising, 
etc. In this respect, the Internet may actually make the position of the new entrant to international operations even more difficult. The new entrant not only has to face the reality of being an unknown amongst a voluminous world of would-be entrants, but also has to face the demands of building experience with using the Internet internationally, of developing a broader range of activities and dealing with a multiplicity of cross-cultural relations in more dispersed markets, and, in the process, link Internet use to other elements of foreign market operations: a tall order, and growing taller. As in the past, newly internationalising companies are bound to look for ways of making this process easier to handle - for example, in the choice of markets to service: psychic distance is unlikely to disappear as a factor in an Internet-influenced world. It may become even more pronounced, reinforced by intellectual property rights considerations, payment security, and related legal concerns.

While the Internet enhances many aspects of the ability of headquarters to control and direct what happens in a multinational's subsidiaries, it does not remove the need for local responsiveness, and in a perverse sense, the Internet and related technology enhance many aspects of local responsiveness - especially in building tighter, common language links to local customers and suppliers, with all the associated strengthening possibilities of face-to-face encounters, sometimes an essential prelude to effective Internet-based relationships. Companies will undoubtedly go through a variety of approaches in the course of modifying management approaches to take account of the realities and possibilities of the Internet. This is already evident in the use of staff in foreign assignments. Companies appear to be testing the limits of the possibilities of virtual assignments, although it appears that these still have to be supplemented with a range of visiting arrangements, short of full expatriation. In this, as in many other areas, as people in all countries learn how to use the Internet to more effectively carry out international business, a blending of 'old forms' of international operations with the power of the Internet is likely emerge - in contrast to the "Internet changes everything" world predicted by some. 


\section{References}

Albaum, G./Strandskov, J./Duerr, E., International Marketing and Export Management, $4^{\text {th }}$ ed., Prentice Hall, 2001.

Allen, L., Channel Conflict Crumbles, The Forrester Report, March 2000 (www.forrester.com), pp. 1-16.

Ayal, I./Zif, J., Market Expansion Strategies in Multinational Marketing, Journal of Marketing, 43, 2, 1979, pp. 84-94.

Bartlett, C.A./Ghoshal, S., Transnational Management, $3^{\text {rd }}$ ed., Boston, MA: McGraw Hill, 2000.

Benito, G.R.G./Welch, L.S., Foreign Market Servicing: Beyond Choice of Entry Mode, Journal of International Marketing, 2, 2, 1994, pp. 7-27.

Blaine, M.J. /Bowen, J., The Role of Information Technology in International Business Research, in Roche, E.M./Blaine, M.J. (eds.), Information Technology in Multinational Enterprises, Cheltenham, UK: Edward Elgar, 2000, pp. 21-56.

Borsheim, J.H./Solberg, C.A., The Internationalization of Born Global Internet Firms, Cahiers de Recherche, Bordeaux École de Management, Talence, France, 2002.

Buckley, P./Casson, M., The Future of the Multinational Enterprise, London: Macmillan, 1976.

Burenstam-Linder, S., An Essay on Trade and Transformation, Uppsala: Almqvist and Wiksell, 1961.

Cohendet, P./Kern, F./Mehmanpazir, B./Munier, F., Knowledge coordination, competence creation and integrated networks in globalised firms, Cambridge Journal of Economics, 23, 1999, pp. 225-241.

Coltman, T./Devinney, T./Latukefu, A./Midgley, D.F., E-business: Revolution, Evolution, or Hype? California Management Review, 44, 1, 2001, pp. 57-86.

, E-Business in the Manufacturing Industry - A Survey Study of International Marketing Profiles of Danish Firms [Danish title: E-business i industrien - en undersøgelse af virksomhedernes internationale afsætningsprofil], Copenhagen: Confederation of Danish Industries, 2002.

Cross, R./Borgatti, S.P./Parker, A., Making Invisible Work Visible: Using Social Network Analysis to Support Strategic Collaboration, California Management Review, 44, 2, 2002, pp. 25-46. 
Daft, R.L./Lengel, R.H., Organizational Information Requirements, Media Richness and Structural Design, Management Science, 32, 5, 1986, pp. 554-571.

Dowling P.J./Welch D.E./Schuler R.S., International Human Resource Management: Managing People in a Multinational Context, $3^{\text {rd }}$ edition, Cincinatti, $\mathrm{OH}$ : South-Western College, 1999.

Economist, The Death of Distance, September 30, 1995, Special Section, pp. 5-7.

Economist, The New Economy: Solving the paradox, September 23, 2000, Special Section on the New Economy, pp. 8-13.

Economist, Outsourcing to India, May 5, 2001, pp.61-63.

Economist, Tongues of the Web, Technology Quarterly, March 16, 2002, pp. 20-22.

Global Reach. Website: http://www.glreach.com/globstats/

Gupta, A.K., The Multinational Enterprise in the Digital Age, Presentation at the AIB Annual Meeting, San José, Puerto Rico, June 28 - July 1, 2002.

Halliburton, C./Jones, I., Global Individualism - Reconciling Global Marketing and Global Manufacturing, Journal of International Marketing, 2, 4, 1994, pp. 79-88.

Japan External Trade Organization, JETRO launches "Virtual IT Mission to Australia", JETRO press release, February 20, 2002.

Kayworth, T./Leidner, D., The Global Virtual Manager: A Prescription for Success, European Management Journal, 18, 2, 2000, pp. 183-194.

Knight, G./Cavusgil, S.T., The Born Global Firm: A Challenge to Traditional Internationalization Theory, Advances in International Marketing, 8, 1996., pp. 11-26.

Kotha, S., Mass Customization: Implementing the Emerging Paradigm for Competitive Advantage, Strategic Management Journal, 16 (Summer) Special Issue (Technological Transformation and the New Competitive Landscape), 1995, pp. 21-42.

Kotha, S./Rothaermel, F.T./Steensma, K., Technological Sophistication versus Cultural Similarity: An Empirical Analysis of Country Factors Influencing Location Decisions in the Internationalization of Internet Firms, Strategic Management Journal, forthcoming.

Leamer, E.E./Storper, M., The Economic Geography of the Internet Age, Journal of International Business Studies, 32, 4, 2001, pp. 641-666. 
Leonidou, L.C., Empirical Research on Export Barriers: Review, Assessment and Synthesis, Journal of International Marketing, 3, 1, 1995, pp. 29-43.

Leonidou, L.C./Katsikeas, C.S., Export Information Sources: The Role of Organizational and Internationalization Influences, Journal of Strategic Marketing, 5, 1997, pp. 65-87.

Lituchy, T.R,/Rail, A., Bed and Breakfasts, Small Inns and the Internet: The Impact of Technology on the Globalization of Small Businesses, Journal of International Marketing, 8, 2, 2000, pp. 86-97.

Lynch, P.D./Beck, J.C., Profiles of Internet Buyers in 20 Countries: Evidence for RegionSpecific Strategies, Journal of International Business Studies, 32, 4, 2001, pp. 725-749.

Macdonald, S., Informal Information Flow and Strategy in the International Firm, International Journal of Technology Management, 11, 1/2, 1996, pp. 219-232.

Madsen, T.K./Servais, P., The Internationalization of Born Globals: An Evolutionary Process, International Business Review, 6, 6, pp. 561-583.

Marshall, P./McKay, J., Evaluating the Benefits of Electronic Commerce in Small and Medium Enterprises, Australian Journal of Information Systems, 9, 2, pp. 135-148.

McAuley, A., The Perceived Usefulness of Export Information Sources, European Journal of Marketing, 27, 10, 1993, pp. 52-64.

Mol, M.J./Koppius, O.R., Distance is not Dead: Why there is an L-Factor in Virtual Organisations, presented at the $25^{\text {th }}$ Annual EIBA Conference, UMIST, Manchester, UK, December 1999.

Oxelheim, L., Financial Markets in Transition. Globalization, Investment and Economic Growth, London: International Thomson Business Press, 1997.

Oxley, J./Yeung, B., E-commerce Readiness: Institutional Environment and International Competitiveness, Journal of International Business Studies, 32, 4, 2001, pp. 705-723.

Petersen, B./Welch, L.S./Liesch, P., The Internet and Foreign Market Expansion by Firms, Management International Review, 42, 2, 2002, pp. 207-221.

Piercy, N., Export Strategy: Key Markets vs Market Spreading, Journal of International Marketing, 1, 1, 1981, pp. 56-67.

Porter, M.E., Strategy and the Internet, Harvard Business Review, 79, 2, 2001, pp. 63-78.

Quelch, J.A./Klein, L.R, The Internet and International Marketing, Sloan Management Review, 37, Spring, 1996, pp. 60-75. 
Roche, E.M., Information Technology and the Multinational Enterprise, in Roche, E.M./Blaine, M.J. (eds.), Information Technology in Multinational Enterprises, Cheltenham, UK: Edward Elgar, 2000, pp. 57-90.

Sarkar, M./Butler, B/Steinfield, C., Cybermediaries in Electronic Marketspace: Toward Theory Building. Journal of Business Research, 41, 3, 1998, pp. 215-221.

Seringhaus, F.H.R., The Role of Information Assistance in Small Firms' Export Involvement, International Small Business Journal, 5, 2, 1986, pp. 26-36.

Shapiro, C./Varian, H, Information Rules. Cambridge, MA: Harvard Business School Press, 1999.

Tse, D.K./Gorn, D.J., An Experiment on the Salience of Country-of-Origin in the Era of Global Brands, Journal of International Marketing, 1, 1, 1993, pp. 57-76.

Vahlne, J-E./Johanson, J., New Technology, New Companies, New Business Environments and New Internationalisation Processes? In Havila, V./Forsgren, M./Håkansson, H. (eds.), Critical Perspectives on Internationalisation, Oxford, UK: Elsevier Science, 2002, pp. 209-227.

Vernon, R., International Investment and International Trade in the Product Cycle, Quarterly Journal of Economics, 80, 2, 1966, pp. 191-207.

Welch, D.E./Welch, L.S./Marschan-Piekkari, R., The Persistent Impact of Language on International Operations, Prometheus, 19, 3, 2001, 193-209.

Welch, L./Loustarinen, R., Internationalization: Evolution of a Concept, Journal of General Management, 14, 2, 1988, pp. 34-55.

Westbrook R./ Williamson, P., Mass Customization, European Management Journal,11, 1, 1993, pp. 38- 45 .

Widdows, R./Widdows, K.L., Sisyphus at his Exercise: The Internet and Consumer Relations in the U.S., in Macdonald, S./Nightingale, J. (eds.), Information and Organization, Amsterdam: Elsevier Science, 1999, pp. 215-228.

Wunderman, W., The future of selling via the Internet. The online progress of disintermediation, Web Commerce Today. Issue 10, May 15, 1998. http://www.wilsonweb.com/wct1/980515wunderman.htm.

Yip, G.S., Global Strategy in the Internet Era, Business Strategy Review, 11, 4, 2000, pp. $1-14$. 
Products and

Value Chain Activities ('What')

Sales (of goods, services, information), manufacturing, R\&D, logistics, etc.
Operation Methods

/Control

('How')

Exporting, contractual methods (e.g. franchising), wholly-owned methods (e.g. sales subsidiary)

\section{Markets/ \\ Geographical Spread \\ ('Where')}

Location of firms' activities

customers, suppliers,

network partners, etc.
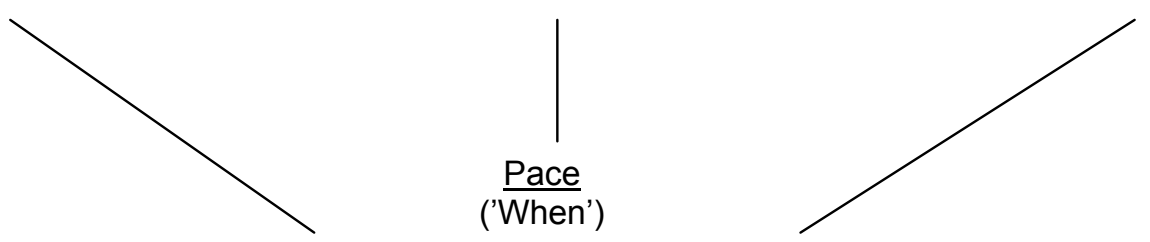

Speed of development of international operations
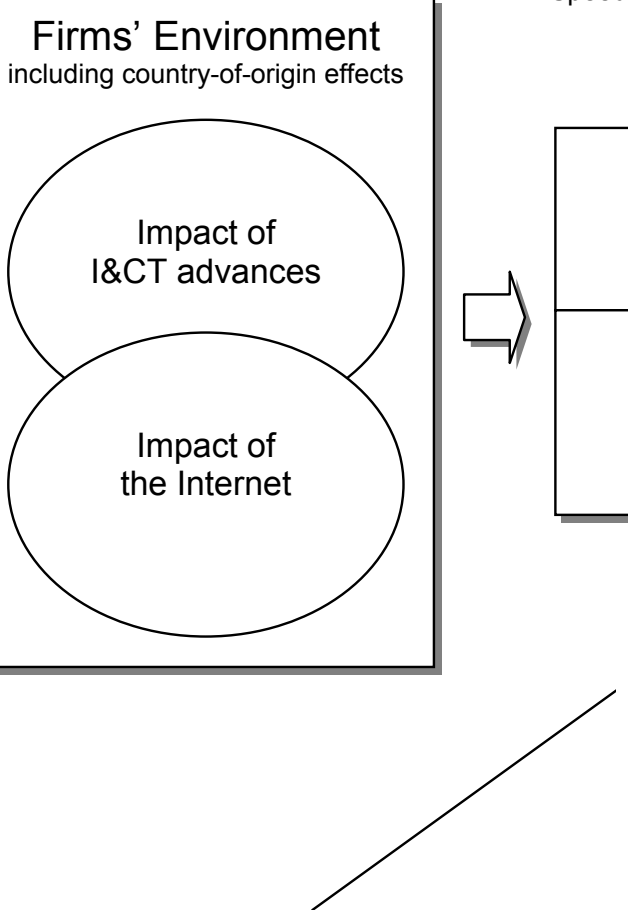

Technology Resources /Production Economies

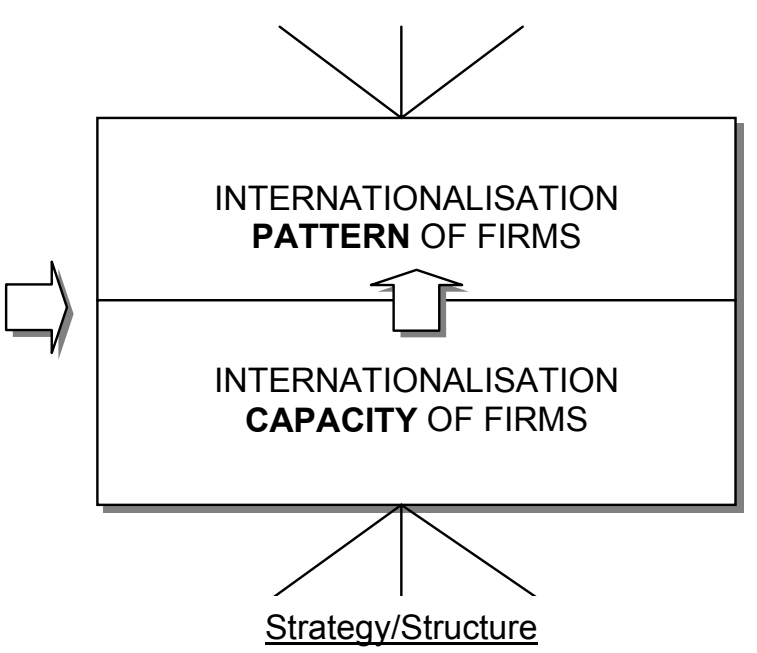

International StrategyOrganisational Structure/Processes<smiles>C1CC1</smiles>

Human Resources IExpertise

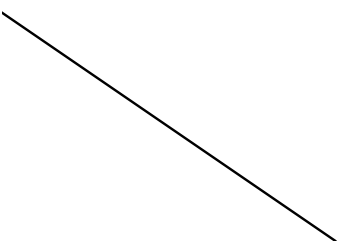

Financial Resources

Figure 1 Various dimensions of firms' internationalisation (Adapted from Welch and Luostarinen 1988) 


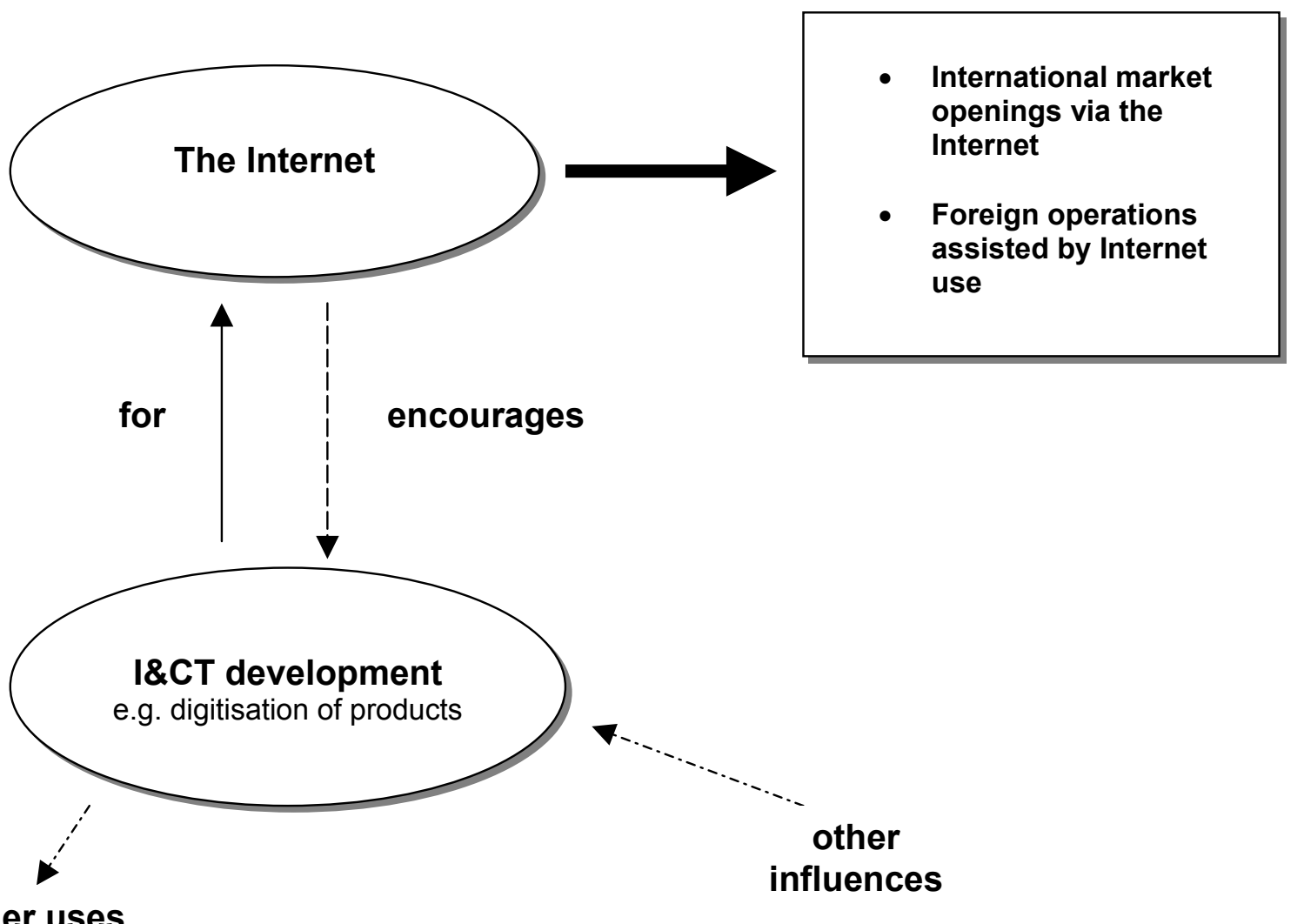

other uses

Figure 2: $\quad$ The Internet, I\&CT development, and internationalisation 
Table 1 Major effects of I\&CT advances and Internet on firms' internationalisation capacity

\begin{tabular}{|c|c|c|c|}
\hline $\begin{array}{l}\text { INTERNATIONALISATION } \\
\text { CAPACITY OF FIRMS }\end{array}$ & General I\&CT advancement effect(s) & Specific Internet effect & Unresolved Internet key issues \\
\hline $\begin{array}{l}\text { Technology Resources } \\
\text { /Production Economies }\end{array}$ & $\begin{array}{ll}\text { - } & \text { Product digitisation encourages } \\
\text { internationalisation of firms } \\
\text { - } & \text { Process digitisation reduces } \\
\text { need for internationalisation }\end{array}$ & $\begin{array}{l}\text { Improved conditions for sharing of } \\
\text { production facilities and technology } \\
\text { resources between firms }\end{array}$ & $\begin{array}{l}\text { Does the Internet ease firms' } \\
\text { assessment of their competitive } \\
\text { advantage in foreign markets? }\end{array}$ \\
\hline $\begin{array}{l}\text { Human Resources } \\
\text { /Expertise }\end{array}$ & $\begin{array}{l}\text { Improved conditions for expatriation } \\
\text { and short term assignments }\end{array}$ & $\begin{array}{l}\text { Improved conditions for virtual } \\
\text { assignments }\end{array}$ & $\begin{array}{l}\text { Exacerbation of culture/language- } \\
\text { related conflicts within the } \\
\text { international organisation? }\end{array}$ \\
\hline Financial Resources & $\begin{array}{l}\text { Global convergence of cost of capital } \\
\text { of international firms }\end{array}$ & $\begin{array}{c}\text { First abundant, then scarce, } \\
\text { national capital available to } \\
\text { international e-commerce ventures }\end{array}$ & $\begin{array}{l}\text { Does greater transparency give } \\
\text { easier access to foreign capital for } \\
\text { int'l e-commerce ventures? }\end{array}$ \\
\hline $\begin{array}{c}\text { International Strategy/ } \\
\text { Organisational Structure and } \\
\text { Processes }\end{array}$ & $\begin{array}{l}\text { Enabling multinationality and } \\
\text { transnationality }\end{array}$ & $\begin{array}{l}\text { Pressure for increased global } \\
\text { coordination }\end{array}$ & $\begin{array}{ll}\text { - } & \text { Pressure for increased local } \\
\text { responsiveness? } \\
\text { - } & \text { Centralisation via e-business } \\
\text { hegemony of } \mathrm{HQ} \text { ? }\end{array}$ \\
\hline
\end{tabular}


Table 2 Major effects of I\&CT advances and Internet on firms' internationalisation patterns

\begin{tabular}{|c|c|c|c|}
\hline $\begin{array}{l}\text { INTERNATIONALISATION } \\
\text { PATTERNS OF FIRMS }\end{array}$ & General I\&CT advancement effect(s) & Specific Internet effect(s) & Unresolved Internet key issues \\
\hline Pace (When?) & Accelerated internationalisation & $\begin{array}{l}\text { Accelerated internationalisation } \\
\text { - due to demand side effects }\end{array}$ & $\begin{array}{l}\text { Does the internationalisation of dot- } \\
\text { com firms slow down in later stages? }\end{array}$ \\
\hline $\begin{array}{l}\text { Product/Value Chain Activity } \\
\text { (What?) }\end{array}$ & $\begin{array}{l}\text { - } \quad \text { Digitisation of products } \\
\text { - } \quad \text { Shift from market-seeking to } \\
\text { resource-seeking activities }\end{array}$ & $\begin{array}{l}\text { - Cross-border e-commerce } \\
\text { - Shift from discrete products to } \\
\text { comprehensive solutions }\end{array}$ & $\begin{array}{l}\text { To what extent does the Internet } \\
\text { supersede firms' need for local, } \\
\text { physical presence? }\end{array}$ \\
\hline $\begin{array}{l}\text { Operational Method/Control } \\
\text { (How?) }\end{array}$ & $\begin{array}{l}\text { Use of contractual methods favoured } \\
\text { by improved controllability }\end{array}$ & $\begin{array}{l}\text { - Contractual methods favoured } \\
\text { by broader recruitment base } \\
\text { - } \quad \text { More Internet exports }\end{array}$ & $\begin{array}{l}\text { Does the pressure for global } \\
\text { coordination (induced by the Internet) } \\
\text { cause greater internalisation of foreign } \\
\text { operations? }\end{array}$ \\
\hline $\begin{array}{l}\text { Geographical Spread } \\
\text { (Where?) }\end{array}$ & More diversified country portfolio & $\begin{array}{l}\text { More diversified country portfolio } \\
\text { - due to demand side effects }\end{array}$ & $\begin{array}{l}\text { To what extent does the Internet make } \\
\text { geographical segmentation irrelevant? }\end{array}$ \\
\hline
\end{tabular}

